\title{
BRANDING MALAYSIA AND RE-POSITIONING CULTURAL HERITAGE IN TOURISM DEVELOPMENT
}

\author{
Hanafi Hussin \\ Department of Southeast Asian Studies \\ Faculty of Arts and Social Sciences \\ Institute of Ocean and Earth Sciences (IOES) \\ University of Malaya \\ (hanafih@um.edu.my) \\ Doi: https://doi.org/10.22452/ jati.sp2018no1.6
}

\begin{abstract}
In the regional and global competitive tourism sector, branding Malaysia as Turley Asian has maximally helped the country. The branding efforts have facilitated Malaysia to present itself as a true sign of pluralism, a mixture of harmonious cultures and the true soul of Asia. The in tangible cultural heritage especially food heritage and traditional performing arts have also significantly contributed to branding 'Malaysia Truly Asia'. The multiple traditional and cultural performances represent multicultural Malaysia. In these performances, all ethnic groups, i.e. Indian, Chinese, Malay, Indigenous and others are represented adequately. Malaysian traditional cuisine also represents the pluralism of Malaysian society. Authentic and hybrid foods and the traditional performing arts have made the country a mini Asia or the soul of Asia. Understanding the position and contribution of both traditional food and performing arts to promote Malaysian tourism under the slogan of 'Malaysia Truly Asia' is extremely important in developing the Malaysian tourism sector. Under the concepts of identity and culture as a segment of branding approaches, this article will analyse how cultural heritage has helped to brand Malaysia as Truly Asia for the development of the tourism sector of Malaysia.
\end{abstract}

Keywords: branding, intangible cultural heritage, 'Malaysia Truly Asia', tourism, Malaysia 


\section{Introduction}

The concept of cultural heritage serves various cultural, social and political purposes (Blake, 2000). It has great value for all sectors, but in tourism, it is treaty like a golden opportunity especially when the site or practice is internationally recognized by UNESCO (Caust \& Vecco, 2017). UNESCO has divided the cultural heritage into three main categories or forms of heritage. The first is natural heritage, which is consists of "natural sites with cultural aspects such as cultural landscapes, physical, biological or geological formations". The second is the heritage in the event of armed conflicts (Rossler, 2003). The third is cultural heritage. This form of heritage includes tangible cultural heritage and intangible cultural heritage. Tangible cultural heritage consists of movable and movable cultural and underwater cultural heritage. Intangible cultural heritage includes rituals, performing arts, oral traditions (Caust \& Vecco, 2017), expressions (language), social practices, performing arts, rituals, and celebratory events, knowledge, and practices related to nature and the universe, and traditional or indigenous craftsmanship (UNESCO, n.d.b).

After ten years, in July 2013, Malaysia became a party to the International Convention for the Safeguarding of the Intangible Cultural Heritage (CSICH), 2003 (Van Uytsel, 2016). In the literature, the concept of intangible cultural heritage especially performing arts and gastronomy (food) in Malaysia has gained little attention concerning its role in the tourism sector. More focus is paid on the legal aspects and measures (Azmi, Madieha, Zaky, \& Zaky, 2016; Van Uytsel, 2016) to protect the intangible and all other types of heritage. In practice, however, performing arts and gastronomy has extensively contributed to the tourism sector of the country. For around four decades, Malaysia has been attempting to develop the country through diversified economic activities including tourism that gives good returns to the national revenue. Therefore, many steps are taken to promote the country's tourism through many slogans for attracting the local, regional and international tourists and the private sector for investing in the tourism industry. It is believed that 'Malaysia Truly Asia' is one of the most successful slogans for tourism. This slogan captures and defines the essence of the country's unique cultural diversity and cultural heritage. Under the slogans, various forms of intangible cultural heritage such as food, dance, and music are used as tools to attract tourists. It is distinctive that is why allures tourists to come to Malaysia. This paper will discuss how performing arts and food as 
intangible cultural heritage has helped to promote tourism in Malaysia and brand the country's image.

\section{Methods}

This paper draws data from the secondary sources to assess the impact of various tools of intangible cultural heritage. These secondary sources include academic and non-academic reports, articles and pictorial material.

\section{Branding Tourism Malaysia through 'Malaysia Truly Asia'}

Without discussing the status, place and role of 'Malaysia Truly Asia' (as campaign and slogan) and the tourism sector, it is difficult to situate or locate the role of cultural heritage in the branding of the country. In 2000, the 'Malaysia Truly Asia' campaign was created (The Star Online, 2007). It is the long-running tourism, culture, and nation branding campaign (Anholt, 2008). It has helped Malaysia in its struggle to bring peace and maintain harmony among the religious and ethnic diverse groups. Although, Islam is central to everyday life in Malay society; however, the federal government has placed the high priority on fulfilling the needs of the tourism sector (Henderson, 2003). Malaysia's slogan 'Malaysia Truly Asia' has taken its deep roots in the society. The slogan 'Malaysia Truly Asia' is echoed across the world as part of an expensive advertising campaign funded by the federal government. Since 2000, the federal government along with the state governments has attempted to attract foreign tourists to boost its economy. Over the years, to meet the needs under the slogan, the federal government has taken extensive measures. In 2013, the government had renamed the Malaysian Ministry of Tourism into the Ministry of Tourism, Arts and Culture for the purpose to use culture and heritage as an approach to encourage and attract the international tourists (Hussin, 2018). A list of concerns highlighted in researches (Sudipta \& Sarat, 2010; Yang, Sharif, \& Khoo-Lattimore, 2015; Alkahsawneh \& Alfandi, 2015, a few to mention) disclose that Malaysian authorities have to present a very soft image of the country to counter any negative feelings against the country. Irrespective of the negative views within the academia, in 2013, Malaysia had received 25.72 million tourists, which brought 65.44 billion to the national economy. In 2017, around 25.9 million global (figure 1) tourists had brought RM82.1 (figure 2) billion and this is major contributions to the revenue (Hussin, 2018). Under the Malaysia Tourism Transformation Plan, Malaysia aimed to bring in 36 million tourists in the country by 2022 (Omar, Karim, 
Bakar, \& Omar, 2015). The Ministry's had the vision to develop the country the world-class cultural and tourist destination by 2022 and also to create the national identity based on arts and culture (Ministry of Tourism, Arts and Culture Malaysia, n.d.). In the tourism policy, the government had declared 2020 as Visit Malaysia Year and aimed to host the major international events including APEC (Asia-Pacific Economic Cooperation) Summit, the Commonwealth Heads of Government Meetings and World Congress Information Technology (Basyir, 2017).

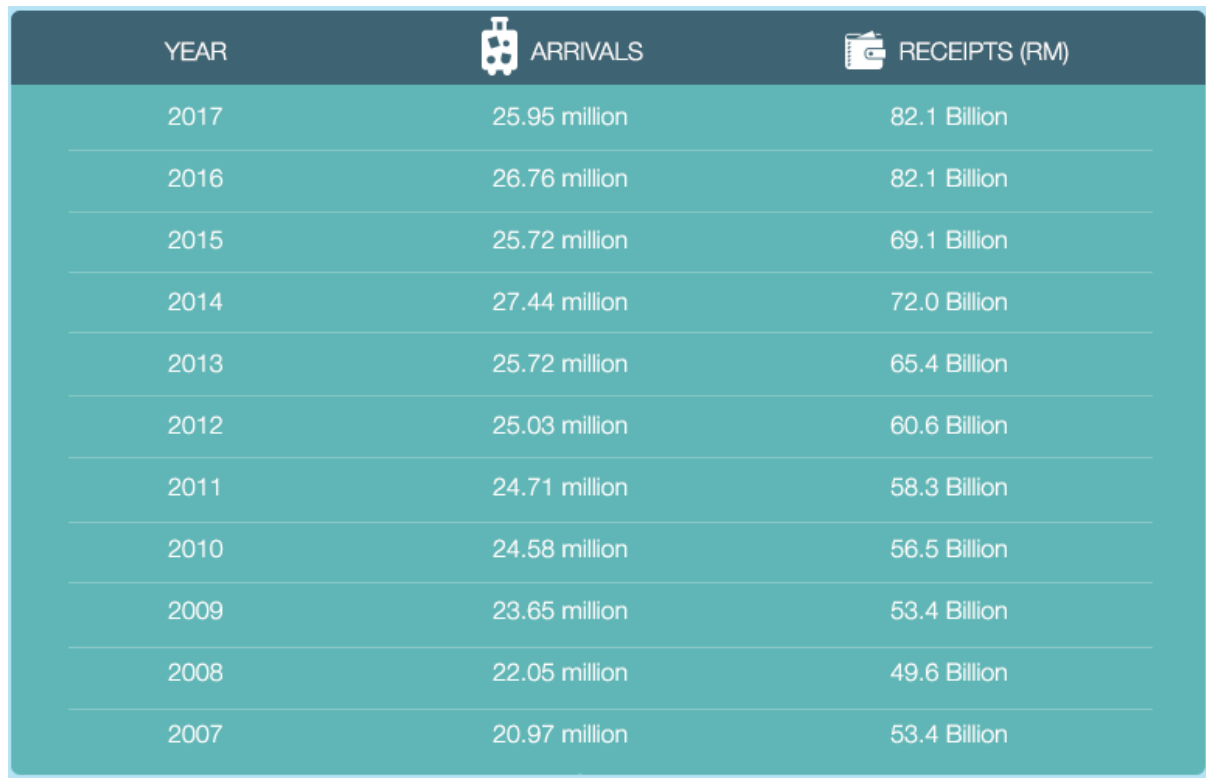

Figure 16: In the table, the number of tourists arrived and receipts to Malaysia, 20072017

(Source: Tourism Malaysia [n.d.].)

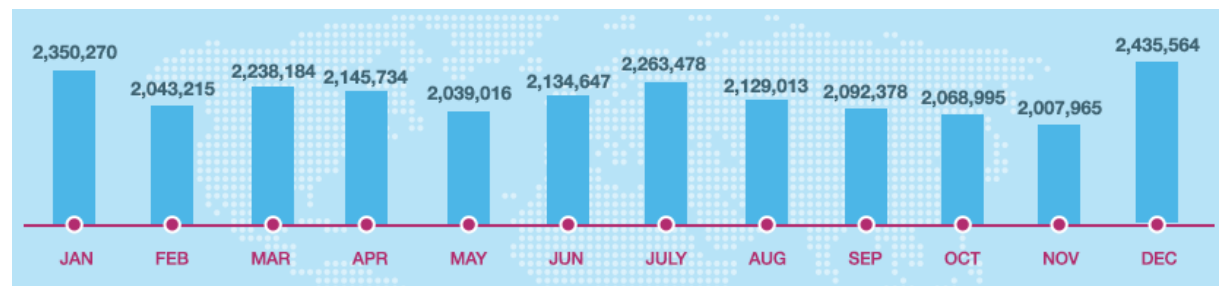

Figure 17: Tourist arrival in Malaysia in 2017

(Source: Tourism Malaysia [n.d.].)

The slogan of 'Malaysia Truly Asia' is the main strategy to give a positive impression to the outsiders that the country is exceptional and unique 
because of the diversity of religious, social, cultural and ethnic groups. By using of the slogan, Malaysia show the world that it is a unique tourism destination with all kinds of flavors, colors, sounds and sights of Asia come together" (Ministry of Tourism, Arts and Culture Malaysia, n.d.). Only Malaysia had Asia's three major ethnic groups, i.e. Malays, Chinese, and Indian. Malaysia claimed that no other country had a diversity of cultures, customs, traditions, and festivals but Malaysia (Ministry of Tourism, Arts and Culture Malaysia, n.d.). Malaysia has translated the traditions and cultures into new contexts to promote tourism and added new styles (Hussin, 2013). The 'Malaysia Truly Asia' campaign and slogan have aided a more advantageous and lasting image among the international audiences, which has pushed Malaysia to heavily depend on and enhance this kind of country's soft power image instead of venturing into other countries issues. However, only slogans and image building are not sufficient to promote tourism. Its indispensable to heavily invest in infrastructure especially related to tourism (Kadir \& Karim, 2012; Shahbaz, Kumar, Ivanov, \& Loganathan, 2015; Hussin, 2018) for attaining economic growth (Tugcu, 2014). It is the branding of the nation and its image as the diverse and peace-loving, which has brought the trickle-down effects on the local economy. Many other indicators which reveal Malaysia's soft power approach is a far better strategy to materialize more effectively and efficiently its resources (Ooi, 2016; Luhong, 2017). Malaysia's soft power approach especially tourism, arts, and food-related strategies are adequate to succeed in achieving the goals.

\section{Positioning Intangible Cultural Heritage in Malaysia}

The World Tourism Organization recognizes heritage tourism as a subclass of cultural tourism. It means visitations to natural sites such as valued gardens, wilderness areas of scenic beauty, and landscapes and also to observe and witness cultural traditions, places, and values that people proudly practice and preserve. It also includes family life and practices, religious practices (especially rituals), folklore social customs and traditions. Additionally, it includes visitation and of museums, battlefields, monuments, historic buildings, artifacts, and landmarks that remind the memory of peace and war, struggles and success stories (Mohamed, Mustafa, \& Rahim, 2005). Cultural heritage is a rapidly growing component in the tourism sector because there is a trend towards an increased specialized taste among tourists. The rising number of tourists seek adventure, culture, archaeology, history, and interaction with local people especially American tourists' interests in 
traveling to cultural/heritage destination has increased over the time and is expected to increase continuously (Hollinshead, 2004). It is shown that heritage and culture were more attractive and brought more satisfaction than various other factors (Foad, Fazel, \& Amin, 2014). In the new Malaysian tourism policy, heritage tourism has been considered as one of the niches and significant product to be developed extensively for the future. Malaysian heritage and multiculturalism are packaged as apart of tourism products that attract both three types of tourists, i.e. ex-colonialists, regional tourists and international tourists (Mohamed, Mustafa, \& Rahim, 2005).

In 1988, Malaysia became a party to the UNESCO's Convention on the Protection of the World Cultural and Natural Heritage. Under the convention two cultural and two natural properties were declared cultural heritage which includes Archaeological Heritage of the Lenggong Valley (declared in 2012), Melaka and George Town, Historic Cities of the Straits of Malacca (declared in 2008), Gunung Mulu National Park (declared in 2000) and Kinabalu Park (declared in 2000) (UNESCO, n.d.a). Other than these four properties, there are no details of cultural heritage properties from Malaysia. However, in academic research, there is much stress on challenges and problems to cultural heritage, its uses, and importance but the scholars such as Ismail, Masron and Ahmad (2014) says that there is a little stress on what could be counted in Malaysian cultural heritage. However, we have a brief description of intangible cultural heritage (a category of cultural heritage) from the Ministry of Tourism, Arts and Culture Malaysia, which stated that "Intangible heritage is a legacy of priority areas that include a heritage that is 'not object' to be enjoyed by the human senses....[it] means an act or gesture of man can be seen, touched, felt, smelt, or heard when it is done or exists, but no longer can be enjoyed when it is missing or expired. The National Heritage Act 2005, says that "Intangible Heritage is including any form of expression, language, utterances, sayings, songs produced by music, not the lyrics, can be heard, singing, folk, oral traditions, poetry, dance, acting as produced through the performing arts, theater, changing sound and music, martial arts, which have existed or exist in relation to the Heritage of Malaysia or any part of Malaysia or Malaysian society in relation to UNESCO" (Ministry of Tourism, Arts and Culture Malaysia, n.d.).

Malaysia's Intangible Cultural Heritage is a response to UNESCO 2003 Convention for the Safeguarding of Intangible Cultural Heritage (ICH) as indicated in the National Heritage Act 2005 (Akta Warisan Kebangsaan Malaysia 2005 (Act 645)). On 23 July 2013, Malaysia handed the DirectorGeneral its instrument of ratification of the Convention for the Safeguarding of 
the Intangible Cultural Heritage. The instrument contains the following declaration: "The Government of Malaysia declares that the application and implementation of the provision of this Convention shall be subject to, and in accordance, the applicable domestic laws of Malaysia and the applicable administrative and policy measures of the government of Malaysia" (UNESCO, 2003).

By the terms of its Article 34, the Convention above will enter into force on Malaysia three months after the date of the submission of this instrument, or on 23 October 2013. Since the drafting and gazetting of the National Heritage Act 2005 (Act 645) in 2005 had helped to protect intangible cultural heritage, especially performing arts food heritage. The position of intangible cultural heritage is increasingly secure because there is a specific provision, Section 49 related declaration as a heritage object by the Commissioner and the provisions of Section 67 are also related to the declaration of the national heritage by the responsible Minister responsible. Similarly, the provisions of Section 112 and Section 113 related to the offense. Section four asks for extending help and support to the preservation and conservation and protection.

\section{The literature on Intangible Cultural Heritage of Malaysia and Tourism}

The literature survey on Intangible Cultural Heritage of Malaysia, from 2001 to 2016 shows that around 171 kinds of literature pieces were produced which consisted of books, journal papers, chapter in the books, research reports, etc.

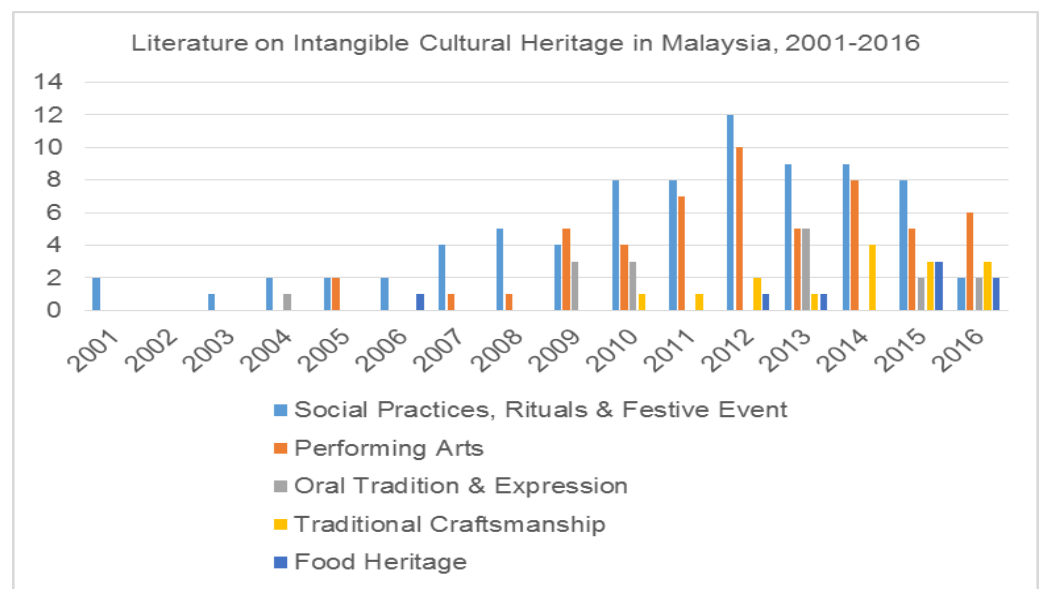

Figure 3: From 2001 to 2016, the literature produced on different dimensions of intangible cultural heritage

(Source: Hussin, 2017) 
It shows the increase of awareness among scholars (local and international), government and non-government agencies towards the safeguarding of the intangible cultural heritage (Hussin, 2017). Between 2001 and 2008, a few literature pieces were produced on intangible cultural heritage categories in Malaysia. These categories included social practices, rituals, and festival events, and performing arts. Afterwards, till 2016, the more literature is produced on other categories of intangible cultural heritage that included oral tradition and expression, traditional craftsmanship and food heritage (see Figure 3).

Today, in Malaysia, cultural heritage tourism has come up as a potential form of important tourism component for both in ternational tourists as well as Malaysian domestic travelers. The cultural, social and religious differences of ethnic groups in Malaysia have brought different local knowledge discipline ranging from its architecture, handicrafts, traditional attire, music and dance, which reflect a colorful amalgamated culture (Ismail, Masron, \& Ahmad, 2014). In Malaysian, tangible and intangible cultural heritage have attracted an increasing number of domestic and international tourists as the needs of the tourists have evolved from the mere satisfaction of curiosity and recreation to a learning experience and appreciation of the indigenous cultures. In traditional times, religious pilgrimages often included the appreciation of local heritage (Gable \& Handler, 1996). Malaysia is proud of its diverse ethnic groups. This diversity has become an invaluable asset to the Tourism Malaysia especially in promoting the diverse Malaysian cultures as one of the tourism commodities. Malaysian Tourism brochures signify the diverse ethnic groups of Malaysian reflecting a multicultural environment, which has turned Malaysia into a fascinating tourism destination. It can be observed from words in the brochure "fascinating people, an enthralling range of attractions and the delightful multicultural fabric of Malaysia". These italic words are linguistic cues, which significantly highlight the diversity of Malaysian ethnic groups. The five cultural elements, i.e. festivals, traditional lifestyles, traditional music, traditional dance, and traditional games are portrayed in Malaysian tourism brochures. These elements are vital sources for Malaysia because these attract the tourist interests in seeing the uniqueness of others (Hanita, 2014). It is extremely important for Malaysia to preserve its cultural heritage to educate its current and future generations. Whether the heritage is part of the national interests or not, the tourism sector has to use to attract the tourists; it relies on historical, natural and indigenous sites to gain the profit (Ismail, Masron, \& Ahmad, 2014). 


\section{Traditional Performing Arts of Malaysia and Tourism}

Malaysia has formed various cultural policies and institutions to promote culture and cultural practices. The tourism is a prime purpose behind all these initiatives; however, these were also meant to unite different ethnic groups. The government has used performing arts to attempt to attempt at social and political control (Tan, 1989). Intangible cultural heritage, particularly performing arts (music, dance and martial arts) and food heritage plays an important role to brand the Malaysian tourism sector.

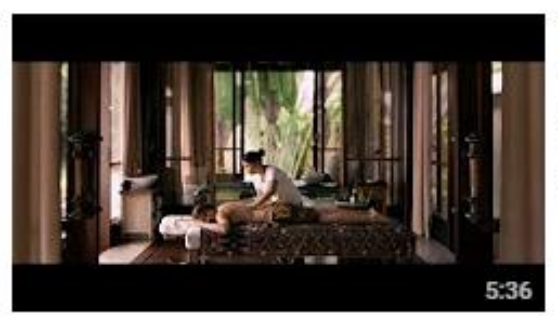

\section{The Essence of Asia by Yuna (5mins)}

Malaysia Truly Asia

2 years ago $\cdot 2,415,589$ views

Visit Malaysia Year 2014 \#VMY2014 MALAYSIA TRULY ASIA You'll love Malaysia now and forever Different races everywhere ...

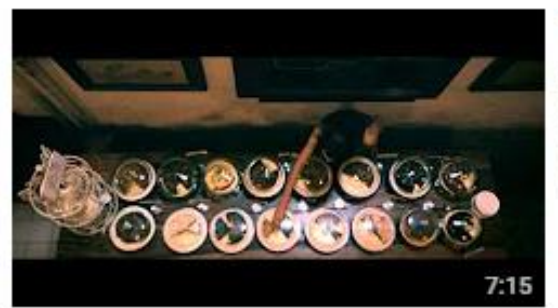

\section{The Essence of Asia by Yuna (7mins)}

Malaysia Truly Asia

2 years ago $\cdot 74,238$ views

Visit Malaysia Year 2014 \#VMY2014 MALAYSIA TRULY ASIA You'll love

Malaysia now and forever Different races everywhere...

Figure 4: ‘Malaysia Truly Asia’ Promotion (YouTube, 2010)

Through short videos, the country has promoted and featured Malaysia as Truly Asia. The first video promotion featuring Khadijah Ibrahim as the singer entitled 'Malaysia Truly Asia' (YouTube, 2010.) and the latest 'Malaysia Truly Asia' video promotion entitled "The Essence of Asia" featuring Yuna as the singer (YouTube, 2014, 7 minutes and 5 minutes) (Figure 4). Through the video "The Essence of Asia," Malaysia is branded as Malaysia as Truly Asia and the intangible cultural heritage is part of it. Brief video clips of performances are prepared, taking from 7 minutes video, which feature Datun Julud (Orang Ulu of Sarawak) (figure 5), Zapin Sindang Dance (Malay of Sarawak) (figure 6), Alu-Alu Dance (Melanau of Sarawak) (figure 7), Rejang Be'uh Dance (Bidayuh of Sarawak), from 5 minutes video (figure 8), Bharata Natyam (Indian Classical dance) (figure 9), Silat (Martial Art) of the Malay (figure 10), Gasing (spinning top) (figure 11) and Chinese Opera (figure 12). 
These dance performances are the intangible art and image of the country (as Looper [2009] envisaged) which in this promotional video represented by multi-racial Malaysia featuring dancers in multi-ethnic dance costume (figure 13) performing sitting dance and singing.

\section{Dance}
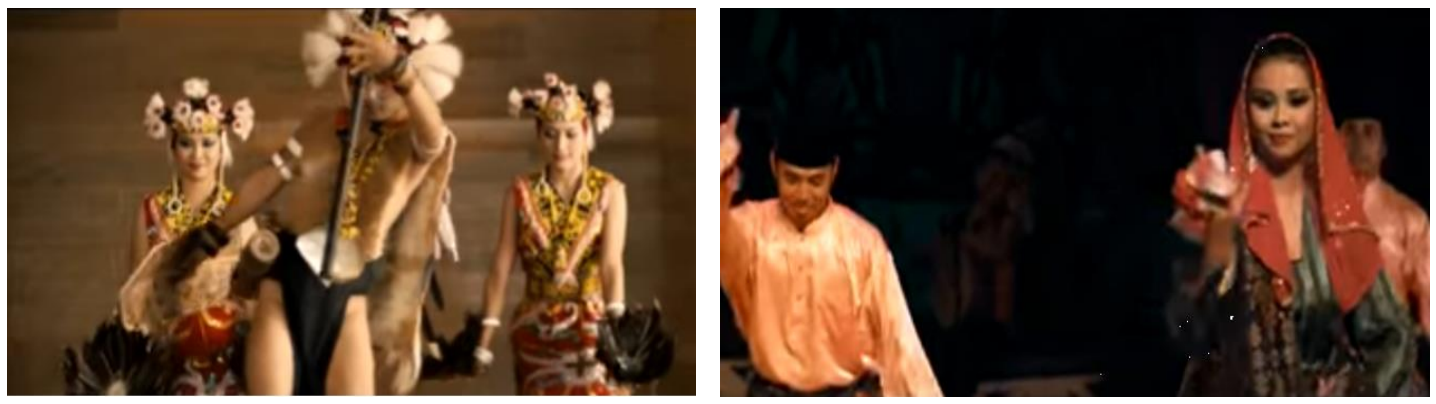

Figure 5 (left): Datun Julud of Orang Ulu Sarawak, 1:02-106, 1:02-1:03(1s), 1:041:07 (3s), and 2.27-2:31 (4s); Figure 6 (right): Zapin Sidang of the Malay of Sarawak 1:07-1-10 (3s)
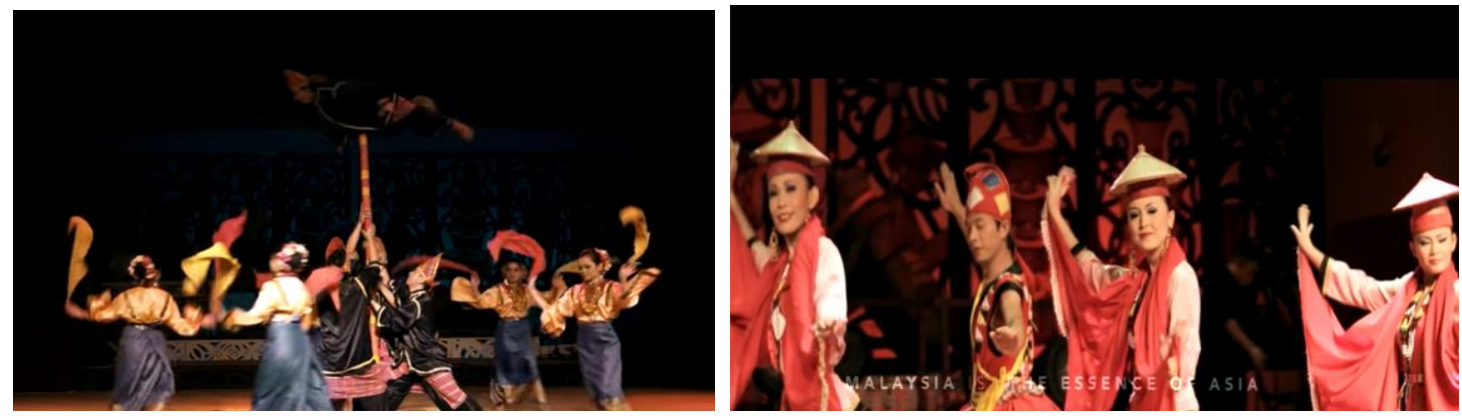

Figure 7 (left): Alu-alu Dance of Melanau of Sarawak, 0:53-0:56 (3s) 1:02-1:04 (2), 6:52-7:00(9); Figure 8 (right): Bidayuh 5:11 / 5:35 (2s), 5 minutes video 

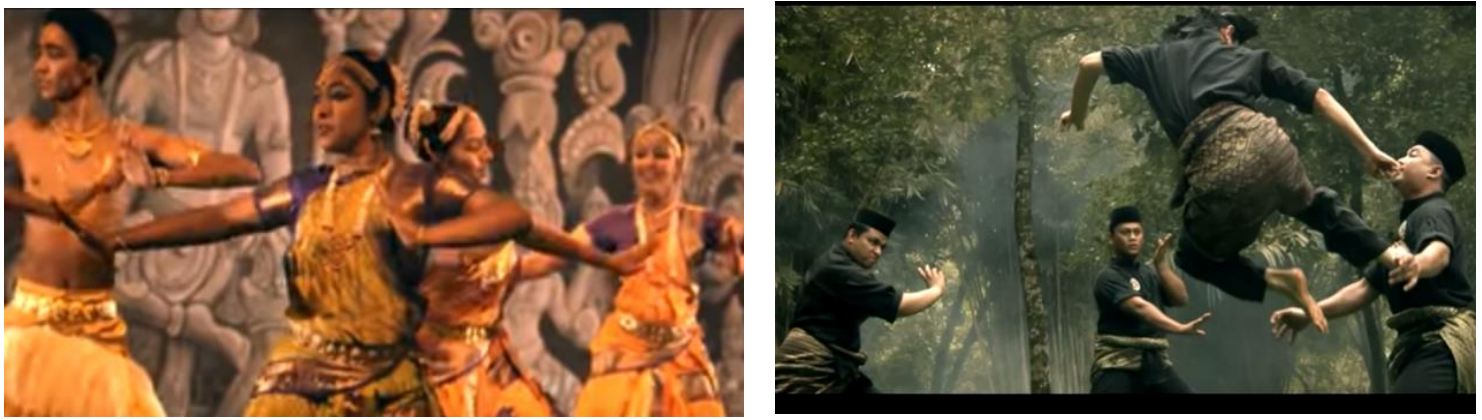

Figure 9 (left): Bharata Natyam (Indian Classical dance) 0:57-1:02 (5s); Figure 10 (righe): Silat (Martial art) of the Malay 2:48-2:57 (9s)
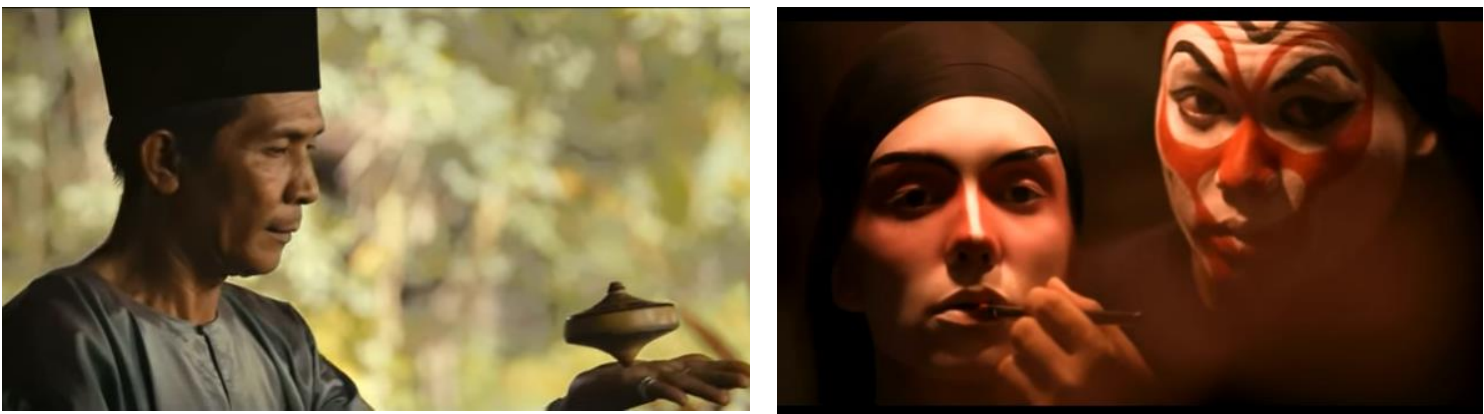

Figure 11 (left): Spinning top, 3:09-3:22 (12s), Figure 12 (right): Chines Opera make-up, 3:28-3:34 (6s)

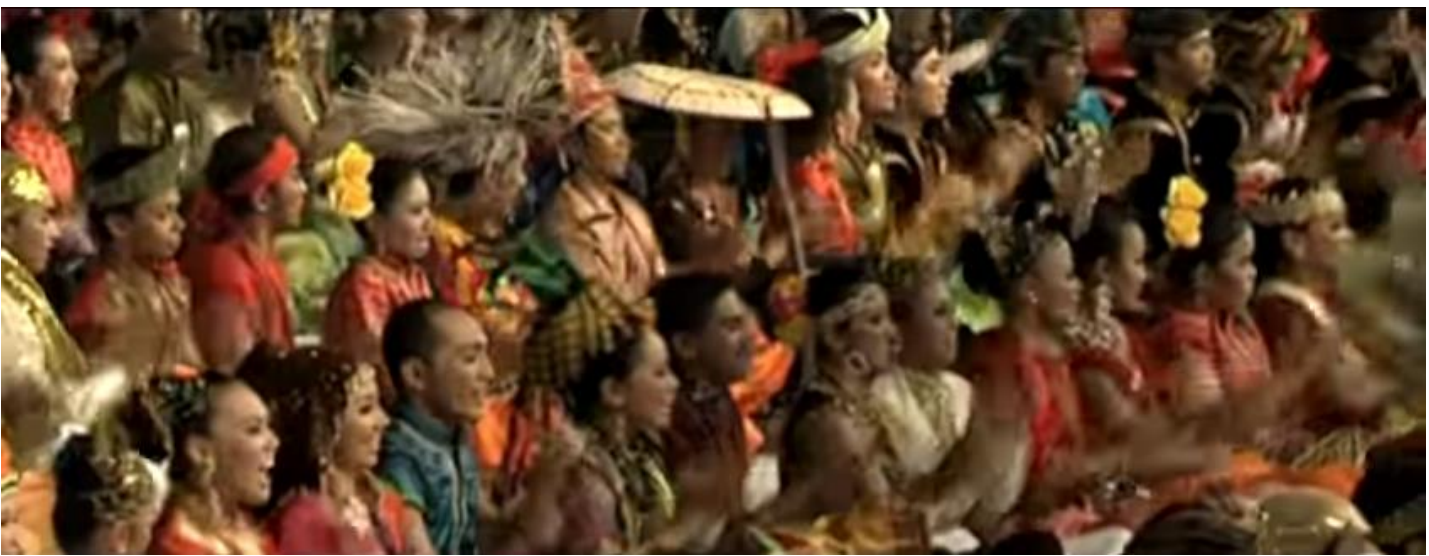

Figure 13: Multi-racial singing and dance, 5:42-5:49 (7s) 


\section{Music}

Similarly, Malaysian traditional songs with a diversity of traditional and ethnic instruments are projected to promote the image of the country (Matusky \& Tan, 2017). Among these are Seruling (flute), Pipa (Chinese classical instrument), Malay Gamelan, and Tabla. Music, dance and songs have together formed a national Malaysian culture, and identity (Chopyak, 1987).

Song composition in "The Essence of Asia" by Yuna (YoutTube, 2017-7 minute) is using a variety of Malaysia traditional styles and music accompaniment such as Seruling (flute), Pipa (Chinese classical instrument), Malay Gamelan, and Tabla. In this promotional video, music instrument featuring the Sapeh, string instrument of Orang Ulu (Sarawak) (figure 14).

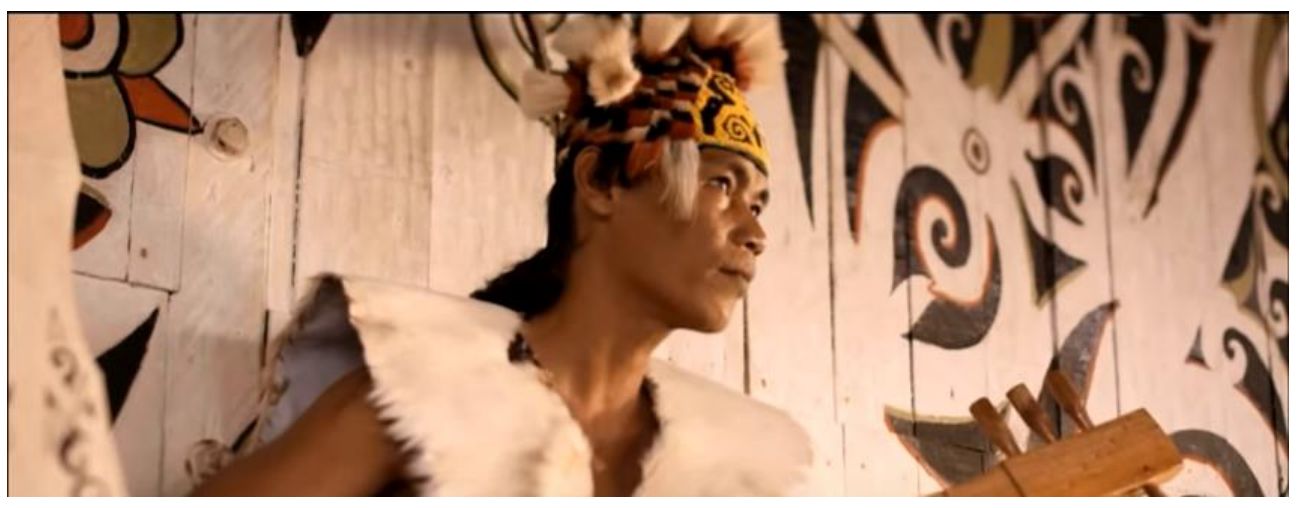

Figure 14: Sapeh music of Orang Ulu of Sarawak, 0:47-0:52 (5s)

\section{Gastronomy and Culinary Custom}

From the tourist's perspective, the link between food culture and place is established by eating locally which helps to elucidate the symbolical consumption of the geographical history of the place that includes the region, province, climate, history, and landscape. In other words, the sacralization of certain tourist sites is used in the local food sector (Laurence \& Marchenay, 2004). In order to expand further, institutional tourism structures are also derived from the available culinary attraction and tourists' needs and desire. Thus, it can be considered as collective rallying points, common frameworks around rural sites which at times become a pilgrimage site for the so-called 'food-tourist' in search of dietary reconciliation. Those act of collection created the similarity between the itinerary of both the tourists and pilgrims. It means 
the self-consciousness of the tourist or pilgrim relates to their decision-making process to visit the site. It involves organizing their trip, from before, during and after the journey (Amirou, 1995).

In Malaysia, the food practices (or food culture) of different ethnic groups will lead to commonly acceptable cuisines, and in the long term, it will construct the Malaysian national food identity (Ramli \& Zahari, 2015). Malaysian food culture is well known for its uniqueness as the food blended in its people representing the pluralism of Malaysia, which consists of Malay, Chinese, Indian, and others. Some of the food blended of authentic and hybrid foods in the selection of delicious culinary delights of Malaysia is also showing the soul of Asia. Malaysian foods are a cultural product, thus, part of the tourism development plan. Malaysia has the vision to be the most competitive food-haven destination in the region. There is a vital link between food heritage as a cultural tourism product and its sustainability in the global, regional and domestic market (Tibere \& Aloysius, 2013). With its new mileage given to gastronomy of Malaysia, 'Food Paradise' where people can taste a diversity of delectable food and distinctive palette, and a tapestry of flavors branding Malaysia is enhanced. Food imagination and tourist imagination are often inter-related as part of the construction of the identity process, especially among the local actors and tourists (Quan \& Wang, 2004). As discussed earlier, food culture is playing a big role in tourism in Malaysia which can be seen in the 'Malaysia Truly Asia' video promotion. The food segment featuring epic food of Malaysia representing Malay, Chinese and Indian through Satay (figure 15), Roti Canai (figure 16), Char Kue Teow and Teh Tarik (literally pulled tea) (figure 17) is a calling to the tourist to taste and experiencing the food culture of Malaysia.

Food heritage and food culture are not only displayed in the promotional video, but it also appeared in many posts at the Malaysia Tourism Board website.
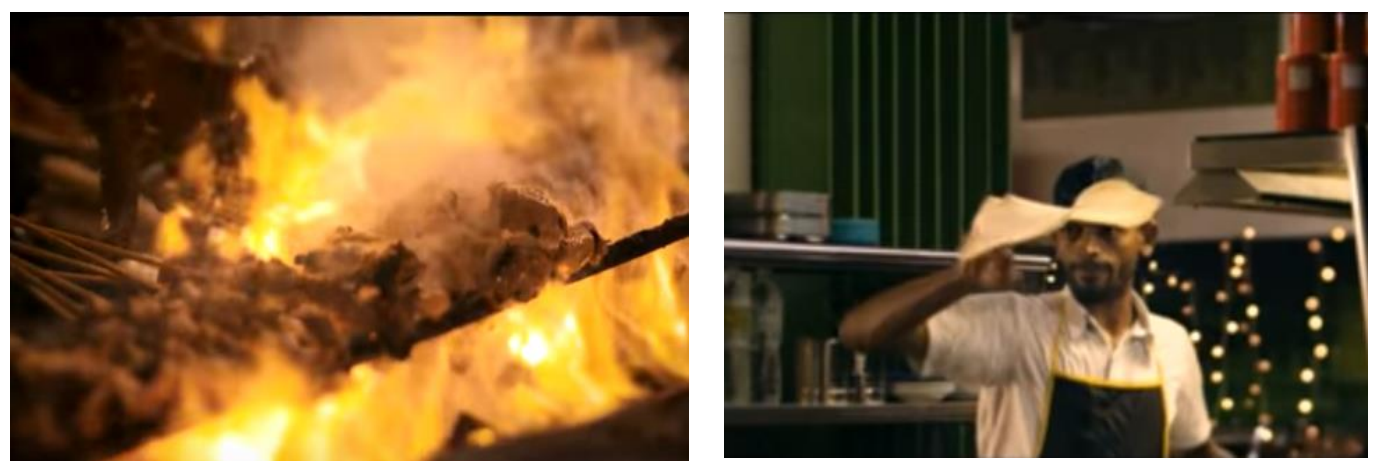

Figure 15: Satay 5:19-5:24 (5s); Figure 16: Roti Canai, 5:24-5:30 (7s) 


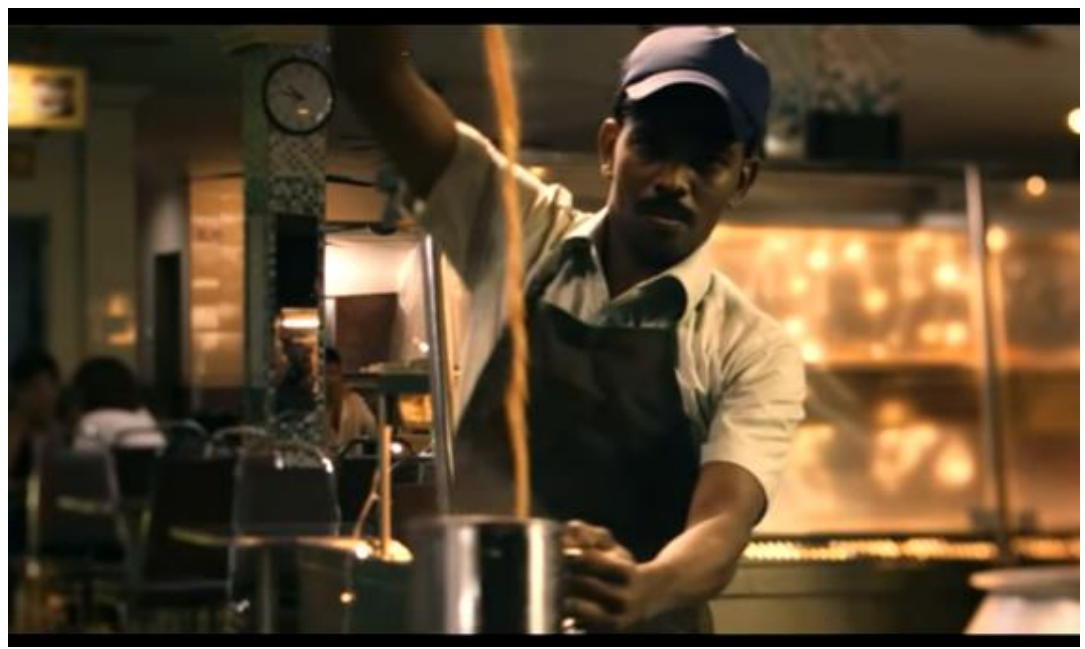

Figure 17: The Tarik, 5:34-5:38 (4s)

\section{Repositioning cultural heritage in the branding of Malaysia}

The literature and discussion above suggest that cultural heritage especially dance, music and food are no more regional or local but national in their characteristics. These important ingredients of cultural heritage were misrepresented as area and ethnic-specific, but through the branding of the country, dance, music and food elevated to national ranks and earned greater respect, recognition and acknowledgement at international forums and also by the regional and international tourist audiences. Teh tarik (literally known as pulled tea) and roti canai are no longer an Indian beverage and food but national. Similarly, dances and music have turned into national cultural heritage tools, which have played a role in strengthening ties between the groups and also lead to peace and harmony. After viewing and studying the traditional performances that featured in the promotional video "The Essence of Asia", representation and displaying of Malaysia through those performances need to be reviewed. Most of the traditional dances of Sarawak featured in this video whereas the representation of traditional performances of Sabah not existed. The representation of Malaysia as a whole in this "Malaysia Truly Asia" branding of Malaysia is arguable. As Malaysia consists of 13 states and 3 federal territories with multi-racial people and multicultural practices should be well presented as Malaysian. Therefore the displaying of their culture, heritage and tradition should be positioned properly. 


\section{Conclusion}

The article shows that the diverse Malaysian intangible cultural heritage has an important position in the country's tourism sector especially to brand the image of the country. With five domains under UNESCO categorization, intangible cultural heritage is especially performing arts (music and dance), material art and food heritage helping the promotion of the country and branding Malaysia as Truly Asia. The audio-visual promotion since the launching of slogan and concept of Malaysia Truly Asia has successfully attracted the huge number of tourists from across the world. The number of tourists arrival has been increasing every year, and tourism is one of the major contributors to the GDP of Malaysia. The tourism sector, therefore, has an important place in the branding the image of the country. After the launching of Malaysia Truly Asia as tourism branding, Tourism Malaysia has renewed the promotion strategy. Since the audio-video is one the best promotion kits, Malaysia Truly Asia branded through an interesting video highlight Malaysia as an Essence of Asia by featuring it as a multi-racial and multi-cultural place in the whole of Asia. Many aspects of intangible cultural heritage practised by the three major races in Malaysia (i.e. Malay, Chinese, Indians) and also the indigenous group in Sarawak, Sabah and Peninsular Malaysia seems representing Asia. The Intangible cultural heritage of Malaysia has a good position in the government policy as a national cultural deposit and also very well attended as having commercial value for the development of tourism of Malaysia. However, to enable Malaysian culture well represented, the displaying of all races and ethnic culture should be balanced. These good practices will enable the sustainability of tourism development of Malaysia.

\section{Acknowledgement}

This paper was presented at the ICONSEA 2017 and the abstract has been published in the Regional Journal of Southeast Asian Studies (2018, 3[2]). The authors would like to acknowledge the financialsupport by the University of Malaya under the research grants ER025-2012A, RP005D-13HNE \& RP001A-13SUS.

\section{References}

Alkahsawneh, M. S., \& Alfandi, A. M. T. (2015). Malaysia's perceived image as a tourism destination for Gulf countries potential tourists. European Journal of Business and Management, 7(25), 134-143.

Amirou, R. (1995). Imaginaires et sociabilite du voyage. Paris: Presses universitaires de France. 
Anholt, S. (2008). Nation branding in Asia. Place Branding and Public Diplomacy, 4, 265-269.

Azmi, A. G., Madieha, I., Zaky, N., \& Zaky, S. (2016). Protection of intangible cultural heritage as a viable tourist product: Malaysia as a case study (touristic products and services). Paper presented at the EURASIA Intemational Tourism Congress, Konya, Turkey, 5-7 May. Retrieved from http://irep.iium.e du.my/53083/

Basyir, M. (2017). 2018 Budget initiatives to elevate tourism to greater heights. Retrieved fromhttps:/www.nst.com.my/news/nation/2017/10/296802/2018budget-initiative s-elevate-touri sm-greater-heights

Blake, J. (2000). On defining the cultural heritage. International \& Comparative Law Quarterly, 49(1), 61-85.

Caust, J., \& Vecco, M. (2017). Is UNESCO World Heritage recognition a blessing or burden? Evidence from developing Asian countries. Journal of Cultural Heritage, 27, 1-9.

Chopyak, J. D. (1987). The role of music in mass media, public education and the formation of a Malaysian national culture. Ethnomusicology, 31(3), 431-454.

Foad, Z. Y., Fazel, H. E., \& Amin, E. (2014). Promoting Tourism Destination: Heritage, History and Culture International Tourism. International Journal of Information Technology and Management Studies, 1(1), 1-32.

Gable, E., \& Handler, R. (1996). After authenticity at an American heritage site. American Anthropologist, 98(3), 568-578.

Hanita, H. (2014). The Presentation of Malaysian Cultures in Tourism Brochures. Procedia-Social and Behavioural Sciences, 118, 140-151.

Henderson, J. C. (2003). Managing tourism and Islam in Peninsular Malaysia. Tourism management, 24(4), 447-456.

Hollinshead, K. (2004). A Primer in Ontological Craft: The Creative Capture of People and Places through Qualitative Research. In J. Phillimore \& L. Goodson (Eds.), Qualitative Research in Tourism: Ontologies, Epistemologies and Methodologies (pp. 63-82). London: Routledge.

Hussin, H. (2013). Rice and performance for the sustenance of traditional heritage in Southeast Asian communities: Selected cases in Borneo, Sabah, Malaysia. In W. Dahlan (Ed.), Asian food heritage: Harmonizing culture, technology and industry, Vol. 1 (pp.17-39). Bangkok: Institute of Thai Studies, Chulalongkorn University.

Hussin, H. (2017). Intangible Cultural Heritage-Survey Summary Report-Malaysia. Report submitted to the International Research Centre for Intangible Cultural Heritage in the Asia-Pacific Region (IRCI) -Mapping Research for the Safeguarding of $\mathrm{ICH}$ in the Asia-Pacific Region.

Hussin, H. (2018). Gastronomy, Tourism, and the Soft Power of Malaysia. SAGE Open, 8(4). Retrieved from https://doi.org/10.1177/2158244018809211 
Ismail, N., Masron, T., \& Ahmad, A. (2014). Cultural heritage tourism in Malaysia: Issues and challenges. SHS Web of Conferences, 12, 01059-p.1-01059-p.8.

Kadir, N., \& Karim, M. Z. A. (2012). Tourism and economic growth in Malaysia: Evidence from tourist arrivals from ASEAN-S countries. Economic ResearchEkonomska Istraživanja, 25, 1089-1100.

Laurence, B., \& Marchenay, P. (2004). Les produits de terroir: Entre cultures et règlements. Paris: CNRS Éditions.

Looper, M. G. (2009). To be like gods: Dance in ancient Maya civilization. Austin: University of Texas Press.

Luhong, S. (2017, August 1). Does Malaysia or Indonesia have more soft power? Retrieved from https://www.quora.com/Does-Malaysia-or-Indonesia-havemore-soft-power

Matusky, P., \& Tan, S. B. (2017). The music of Malaysia: The classical, folk and syncretic traditions. Abingdon: Routledge.

Ministry of Tourism, Arts and Culture Malaysia. (n.d.). Warisan Tidak Ketara. Retrieved from http://www.heritage.gov.my/ms/warisan-tidak-ketara/grpwarisan-tidak-ketara-pengenal an

Mohamed, B., Mustafa, R. A., \& Rahim, A. (2005). Heritage tourism in a multicultural society: The case of Malaysia. Proceedings of 3rd Global Summit on Peace through Tourism, Pattaya, Thailand, 2, 141-147.

Omar, S. R., Karim, S. A., Bakar, A. Z. A., \& Omar, S. N. (2015). Safeguarding Malaysian Heritage Food (MHF): The impact of Malaysian food culture and tourists' food culture involvement on intentional loyalty. Procedia-Social and Behavioral Sciences, 172, 611-618.

Ooi, C. (2016). Soft power, tourism. In J. Jafari \& H. Xiao (Eds.), Encyclopedia of tourism (pp. 1-2). Cham, Switzerland: Springer.

Quan, S, \& Wang, N. (2004). Towards a structural model of the tourist experience: An illustration from food experience in tourism. Tourism Management, 25(3), 297-305.

Ramli, A., \& Zahari, M. S. (2015). Determinants of food heritage in Malaysia context. Paper presented at the $2^{\text {nd }}$ International Hospitality and Tourism Conference 2014, Penang, Malaysia, 2-4 September.

Rossler, M. (2003). World Heritage Site: Toward linking the tangible and the intangible. In D. Harmon \& A. D. Putney (Eds.), The Full Value of Parks, (pp. 197-110). New York: Rowman \& Littlefield Publishers, Inc.

Shahbaz, M., Kumar, R. R., Ivanov, S., \& Loganathan, N. (2015). Nexus between tourism demand and output per capita with relative importance of trade and financial development: A study of Malaysia. Tourism Economics, 23, 168-186.

Sudipta, K. S., \& Sarat, L. (2010). Cultural tourism in Malaysia in the perspective of Indian tourists: A study. Journal of Tourism, 10,48-53. 
Tan, S. B. (1989). The performing arts in Malaysia: State and society. Asian Music, 21(1), 137-171.

The Star Online. (2007, August 16). 'Malaysia Truly Asia' bags three gold awards.

Retrieved from

https:/www.thestar.com.my/news/nation/2007/08/16/malaysia-truly-asia-

bags-three-gold-awards/

Tibere, L., \& Aloysius, M. (2013). Malaysia as a Food-Haven Destination: The Vision and its Sustainability. Asia-Pacific Journal of Innovation in Hospitality and Tourism-APJIHT, 2(1), 37-51.

Tourism Malaysia. (n.d.). Malaysia Tourism Statistics in Brief. Retrieved from http://www.tourism.gov.my/statistics

Tugcu, C. T. (2014). Tourism and economic growth nexus revisited: A panel causality analysis for the case of the Mediterranean Region. Tourism Management, 42, 207-212.

UNESCO. (2003). Convention for the Safeguarding of the Intangible Cultural Heritage 2003. Retrieved from http://portal.unesco.org/en/ev.phpURL_ID=17716\&URL_DO=DO_TOPIC\&URL_SECTION=201.html

UNESCO. (n.d.a). Malaysia: Properties inscribed on the World Heritage List (4). Retrieved from http://whc.une sco.org/en/state spartie s/my

UNESCO. (n.d.b). What is meant by "cultural heritage"? Retrieved from http://www.unesco.org/new/en/culture/themes/illicit-trafficking-of-cultural-

property/unesco-database-of-national-cultural-heritage-laws/frequentlyasked-que stions/definition-of-the-cultural-he ritage/

Van Uytsel, S. (2016). Intangible Cultural Heritage Legislation in Asia: In Search for the Spirit of the 2003 UNESCO Convention. SSRN. Retrieved from https:/papers.ssrn.com/sol3/papers.cfm?abstract_id=2879244

YouTube. (2010). Tourism Malaysia - Malaysia Truly Asia Song with Lyric. Retrieved from https://www.youtube.com/watch?v=4PQe0gedjzY

YouTube. (2014). The Essence of Asia by Yuna (5mins). Retrieved from https:/www.youtube.com/watch? v=rrUXxqxu74k

Youtueb. (2014). The Essence of Asia by Yuna (7 mins). Retrieved from https://www.youtube.com/watch? v=si3 wxbq3yhc

Yang, E. C. L., Sharif, S. P., \& Khoo-Lattimore, C. (2015). Tourists' risk perception of risky destinations: The case of Sabah's eastem coast. Tourism and Hospitality Research, 15, 206-221. 